\title{
ANTHROPONYMS AS MEANS OF EXPRESSION OF THE NATIONAL ESTHETICS OF TARAS MELNYCHUK'S LINGUISTIC WORLD
}

\author{
Zara Tyshchenko \\ Postgraduate Student at the Department of Ukrainian Language, \\ V. N. Karazin Kharkiv National University, Ukraine \\ e-mail: zaratisenko@gmail.com,orcid.org/0000-0002-1807-8709
}

\section{Summary}

The article studies anthroponyms in Taras Melnychuk's poetic linguistic world. The research analyses the semantics of the proper names of the theme groups "national history" and "national literature" and focuses on their ethnolinguistic aspect.

Mostly outlined is the connotation of the proper names that denote the representatives of the national history of the time of princes and the time of the liberation struggle of the $17^{\text {th }}-19^{\text {th }}$ centuries. The epoch of the Kyivan Rus is represented mainly by anthroponyms denoting the princes who were statebuilders (Святослав, Володимир, Ігор and others). The time of the Cossack and peasant movement is represented by anthroponyms that denote personalities widely-known in Ukranian society: Cossack leaders (Богдан Хмельницький, Сірко, Нечай and others) and vigilantes (Довбуш, Кармелюк).

Another powerful identifier of the esthetic mentality of the Sixtiers in T. Melnychuk's works are proper names that outline the literary circle represented in the author's anthroponymicon by the names, surnames and circumlocutions of Ukrainian classics (Сковорода, Tарас and others).

The author's comprehension of the historical discourse, the constant search of historic reasons for losing national freedom, the accentuated dramatic reliving of Ukraine's fate fully represent the dissident worldview.

It is observed that the author's linguistic mind is closely interwoven with mythology and folk song tradition, which points to the main features of the poet's individual style.

Keywords: linguistic worldview, poetic text, individual style, proper names, national-cultural component, semantics

DOI: https://doi.org/10.23856/3814

\section{Introduction}

Linguistic representation of the worldviews of the authors of the generation of dissidents the Sixtiers - remains a topical issue of modern linguopoetics. A bright representative of "the second wave of this social cultural phenomenon" (by M. Ilnytskyi's words) is the "new Franko" (V.Stus), a lyric poet from Kolomyishchyna - Taras Melnychuk. The poet's linguistic wordview reflects "individual beliefs, the Hutsul mythological world, national ideals" (Zelenenka, 2009: 4).

A worldview reproduces the objective material world with "the maximum possible totality of national linguistic means of expression" (Zhaivoronok, 2007: 175). W. von Humboldt said that a language always objectifies the individual character of the entire ethnos. Thus, studying the creative manner of a particular author can be a way to self-understanding of the whole nation.

We see analysis of anthroponyms as an important and interesting area of studying T. Melnychuck's poetic linguistic world. Looking into the corpus of anthroponomical units of the theme groups "national history" and "national literature" of the author's linguistic space is 
worthwhile, considering the through national-cultural marking of the semantics of the anthroponyms as an original feature of the individual style of the dissident lyric poet.

Literature review. T. Melnychuk's poetic works primarily attract the attention of literary scholars, among them are I. Zelenenka, S. Kut, M. Laiuk, T. Pastukh, O. Slonovska, O. Shaf.

The author's linguistic world was studied by modern linguists like Yu. Brailko, K. Diukar, Yu. Zuienko, L. Peni, R. Rizhko, O. Shumeiko. T. Melnychuks works were studied both personally and as part of research of the Ukrainian Poetry of the 20th century, that is as a side line, incomprehensively.

The importance of the present research lies in the fact that the ethnolinguistic aspect of the anthroponymy of T. Melnychuk, a Shevchenko Prize Laureate (1992), still remains scantly studied, though it looks quite interesting from the point of view of the originality of the esthetic-national constant.

The aim is to make a semantic analysis of the nationally marked anthroponyms in Taras Melnychuk's poetic language, to outline the dominant individual stylebuilding features of his linguistic mind. The object of the study is the anthroponymic units of the poetic texts that are part of the three-volume edition of the poet's works.

Discussion. The names that make a certain continuum around every person, a special national-cultural space, which is common for the whole linguistic group (Rylov, 2006: 5) are, to our mind, anthroponymic units of the theme group "history", in particular of the subgroup "national history": the time of Kyevan Rus and the liberation struggle of the $17^{\text {th }}-19^{\text {th }}$ centuries.

In the contexts that are quoted in the present article the author's spelling and punctuation are preserved. They do not sometimes conform with the present rules, but are stylistically justified in most cases. The examples from the poems are given as they are presented in the author's edition (see the references).

In T. Melnychuk's poetic discourse, an example of the languistic units common for Ukrainian society are proper names denoting the representatives of the time of princes, among them the names of:

- defenders and state builders as well as their environment: Володимир, князь Данило, князь Ігор (Ігор-князь), Мономах, Олег, Святослав, Ярополк, Ярославна (Ярославни);

- enemy leaders: Батий, Менглі-Гірей, кончак, Чінгісхан (Чінгіс-хан, чінгісхан). It is observed that characteristic of the anthroponyms of the above theme groups are their large quantity and the abundance of their emotional load.

The anthroponymic units denoting the princes who are defenders have a positive connotation in peculiar historical sketches. An inextricable blood connection with the Ruthenian princes - the glorious ancestors of modern Ukrainians - is observed. For example, the first part of the context "П'є печеніг вино з черепа Святослава / I доки він буде пити кров мою зайда кривава?" (Melnychuk, 2003: 109) presents the historically authentic fact of the Ruthenian prince Sviatoslav Ihoriovych's (938-972) death in the fight with khan Kuria in 972. Considering the specific character of the dissident poet's works, we assume that it is a way of making a projection onto the events of the recent history. The appositional construction зайда кривава in the second part of the quote is the author's means of encoding the Ukrainian people's oppressor of the time - the Soviet totalitarian system. In this way a particular historical reflection "the past - today" is created: печеніг - зайда кривава, вино - кров, з черепа Святослава - мою. By building different chronological axes, such linguistic means determine temporal relations, which points to a temporal function of anthroponyms, O. Bondar argues (Bondar, 1998: 3).

What makes the quote especially expressive is the phrase пити кров, that is to exhaust, to tire out. Such lexical units are the "culture code": very often they encode a whole plot" 
(Teliya, 1996: 224). The idiom, pointing to sense development, bears ethnological information and becomes a powerful emotive expresser. Such linguistic discoveries are distinct features of T. Melnuchuk's individual stylistic character.

The poet uses the image of the Kyivan prince Sviatoslav Vsevolodovych (1116-1194), who, in 1183, took Konchak - the Polovtsian khan, in the folowing lines: "йдуть половці / кончак бритоголовий перевалив через хорол / О Святославе! / I ми готові!.. / Князь ринув нас - переборов! / й 6000 половців загріб я - / в полон шість тисяч кончаків / А по мені тепер погріб'я / подзвіння дзвонів - канчуків / I вже не n'ють шоломом / з Дону вербові котики мої / Й з колгоспу тягну я додому / і хліб й коров'ячі гної” (Melnychuk, 2007: 128). Especially expressive in the poem are the deverbative nouns with abstract semantics - the occasional word погріб' $я$ and the archaic word подзвіння, which are elements of Ukrainian funeral ceremony. In this way the author renders the bitterness of realizing the loss of the freedom spirit by his descendants. The feeling of grief is intensified by the image of a pussy willow tree, which, in Ukrainian ethnoculture, gets energy from water, personifies a viable plant. T. Melnychuk, sympathetically calling his contemporaries вербові котики ("pussy willow catkins"), by means of the appellative gives them the features of spiritual diminutiveness, depicting them as those who cannot win, cannot get rejuvenated by their ancestors' lifeblood. Constant search of historical reasons for losing national freedom is the worldview priorities of the sixtier poets.

The theme group "the time of the liberation struggle of the $17^{\text {th }}-19^{\text {th }}$ centuries" is mostly represented in T. Melnuchuk's works by anthroponyms that denote personalities widely-known in Ukrainian society, namely:

- representatives of the Cossack Epoch: Богдан Хмельницький (Богдан, Хміль, Богдан Хмель, богдан хмельницький, Хмельницький Богдан), Сірко (сірко), Залізняк (Залізняки), Остряниця, Морозенко, наливай, Мазепа (мазепа), палій, полуботок, підкова, тетеря, богун, Гонта, Нечай;

- images of vigilantes: Довбуш (довбуш, довбуи-збуй, Олекса, олекса, Олек, Олекса Довбуш, в Довбушевій порохівниці, у довбушів камінь), Кармелюк (кармелюк, Кармель, Устим, сорочка Кармалюкова). As can be seen from the anthroponymic sample, the very abundance of the variants of the proper names points to a formal ethnic markedness determined by the national significance of the historic personalities.

A deep scar in the folk consciousness was left by the Cossack time. A number of T. Melnychuk's poetic works about Cossack leaders have formed a positive axiological connotation. The dissident poet is sure that Ukrainians lack aspiration for freedom as the main national identifier. The author is worried about the loss of the spirit of ancestors among modern Ukrainians - the descendants of the renowned Cossacks: "тут Сагайдачний в кожнім сериі плаче / пояничарились козачі юнаки / й з дівочих чресел необачних / сипляться на діл потурнаки” (Melnychuk, 2003: 94). The old use words with negative connotation пояничарились, потурнаки accentuate the disparaging attitude to compatriots who do not remember the heroic past of their people.

The direct reminiscence Сагайдачний - необачних, whose prototext is a famous folk song, is seen as a reminder to the modern generation about their Cossack origin. Such a technique contributes to a more dynamic and intense character of the literary work.

The image of ataman Ivan Sirko, who personifies the Cossack outlaws, in the following lines is interpreted as a forerunner of Ukraine getting its independence: "я злечу Україну угору / $i$ сірко у вікно / $i$ за ним з весняного грому <... / гетьмане де ти?" (Melnychuk, 2006: 130-131). The predicate extenders угору, у вікно are positively connotated, as the former points to freedom, height, absolute and the latter symbolizes the opening that lets 
in supernatural power, while both render the meaning of the open, the unlocked. The epithet 3 весняного грому indicates good hopes. The lines show the signs of vitalism - the style movement whose esthetics in Ukraine asserts the vitality of the nation, the immortality of Ukrainian spirit. The vitalistic signs are characteristic of the worldview of the "imprisoned" authors fighters who are full of optimism and belief in the proximity of state independence.

A appeal to learn from historical mistakes is present in the context: " $а$ то життя / наче дурнів / нас штовхає / в спину / пошпотався / під Нечаєм / коник в украӥну” (Меlnychuk, 2007: 153). A certain intertextuality can be seen - it is a paraphrased line from a folk song about Danylo Nechai: “Пошпотався під Нечаєм / Коник на купинку” (Ukrainski narodni dumy ta istorychni pisni, 1990: 130-134). A superimposition of time areas is formed by means of retrospection: a historic personality - modern developments (Nechai - Ukraine). In such a way the author builds up the paradigm freedom - bondage, where the axiological load of the anthroponym is positive, while that of the toponym is negative, that is, the contemporaries with slave psychology do not get freedom. That is why the noun denoting the proper name begins with a capital letter, and the one denoting the toponym begins with a lowercase letter.

There is both positive and negative colouring in the way the poet depicts the images of the Cossack heroes. The developments of the totalitarian Soviet Ukraine, which are openly resisted by Ukrainian dissidents, are the result of the failed attempts to get national freedom, which were taken as far back as by the Cossack atamans and hetmans: "знов зібралися ми / на раду / баба яга / хурчить веретено / палій полуботок / наливай наливай / а на підкову кують / окови / а тетеря - / тайна вечеря / а богун $і$ мазепа - / сто коней / $i$ богдана Хмельницького череп / я вмер / я лечу в безодню / я вас чую / панове гетьмани... / через день / привели притягли / всіх у зону / свої ж отамани” (Melnychuk, 2006: 265-266). The beginning of the context знов зібралися ми на раду has an autobiographic implication - the imprisonment of the poet who associates his dissident cohort with the hetmans who were state builders. In the given context, the image of Baba-Yaha, who impersonates death in pre-Christian beliefs (Rajken, 2005: 21), means fatal danger. Supposedly, by веретено ("spindle") the author means the "chariot of history" (in Ukrainian literally "the wheel of history"), in which the images of famous national leaders pass kaleidoscopically. The mythological Баба Яга (BabaYaha), the biblical тайна вечеря (The Last Supper"), the historical гетьмани, отамани (hetmans, otamans), the jargon зона ("quod") belong to completely different discourses, which are discordant at first sight, but, combined in one lexical image line, point to a deep historical analysis. In search of the reasons for centuries-old absence of great power statehood in Ukraine, Melnychuk skillfully interweaves several linguistic worldviews: the mythological, the biblical, the national-hictorical and the Soviet reality. It demonstrates the author's comprehension of the continuity of history, which is beyond time. It also shows the cause and effect relations, which help to understand that the present is directly made by the past and is inheritable to a certain extent. Such a feature of linguistic mind indicates the depth of the author's view of life.

A close connection of the present developments in Ukraine with its history, in particular, indications of Bohdan Khmelnytskyi's actions, can be traced in the poem Далекі предки (Remote Ancestors): “Сині води... / Жовті води... / Хміль та Хміль, / Та Остряниця. <...> Наварили з хмелю пива - / Наробили собі дива. / Темні лиця, / Темні лиця, / В темні води вам дивиться. / Сині води. / Жовті броди. / Біль та Хміль, / Та Остряниця”" (Melnychuk, 2003: 68). The author uses the form of a folk song to address the winning battle near Zhovti Vody, with which the Cossack and peasant troops headed by Bohdan Khmelnytskyi began the National Liberation War against the Polish Gentry. The state colours blue - yellow point to the people's aim, as it was "the father of national freedom" who laid foundation 
of today's independence. One-word anthroponymic models that denote the nicknames Xмiль, Остряниия make the narrative more intimate, emphasizing people's love for the national heros. But, unlike the folk work, in which the images of the defenders are usually positively connotated, Melnychuk's song is a reproach to the remote ancestors. The allusion наробили собі дива is a suggestion of the fatal historical mistake made by the hetman and the Cossack troops in the rapid stream of the historic events of the far 1654, when they pledged allegiance to Moscow Tsar. The dissident author draws a parallel between history and modern time - once the hetman failed in the fight for Ukraine's freedom and now modern Ukrainians did.

As can be seen, the immersion into different discourses that convey a symbiosis of several linguistic worldviews proves a strong connection of Melnychuk's linguistic consciousness with the memory of generations. The poets's address to the past is determined by the aim to study the cause and effect relations of modern fails in state building rather than the necessity to depict historic developments.

Significant in the anthroponymicon of T. Melnychuk's linguistic works are proper names denoting the images of freedom-loving vigilantes - Oleksa Dovbush and Ustym Karmeliuk, who are depicted with the absolutely positive axiological connotation. The images of the folk heroes symbolise the immortality of Ukrainian nation, for example: "в циих деревах / у сериевині / живе довбуш / кричить / а в ичих кармелюк / $i$ ніхто ичі дерева / не викорчує / як не викорчувати / сониее" (Melnychuk, 2006: 179-180). The spelling of the surnames indicates a certain apellativisation which gives the onyms a new sense - advocates of freedom. In the first line, the demonstrative pronoun $u u x$ - specifies the place - in the Carpathian forests, the metaphor is intensified by the particularizing adverbial modifier of place $y$ сериевинi, that is, in hutsul's heart. The mythologized nature personifies Hutsul region as the region of freedom-loving daredevils. The repetition of the present and future verbs не викорчує, не викорчувати makes the poetic lines more expressively dynamic. This technique shows that the tenacious folk memory preserves the images of the heroes who became a part of Ukrainian mentality. The vitaistic image of the sun in the author's original metaphor не викорчувати соние represents the immortality of Ukrainian people.

Thus, proper names that denote the images of folk leaders, corresponding to a particular time in history, perform the function of localisation as they represent the historic figures that are present in Ukrainians' collective consciousness. In T. Melnuchuk's discourse, the surnames are filled with the author's individual connotations and become the condition of its functioning as an ethnically marked unit.

In Melnychuk's works, an integral part of the corpus of Ukrainian linguistic-poetic worldview and a powerful identifier of the esthetic mentality of the representatives of the intellectual revolt of the 1960-s are the proper names that outline the literary circle which is mostly represented in the author's anthroponymicon by the names, surnames and circumlocutions of the classics: Григорій Савич (Сковорода), Свген Плужник, Леся Українка (Леся), Максим Рильський, Михайло Павлик, Панько Куліш, Тарас Шевченко (Шевченко Тарас, Шевченко, Тарас, Кобзар), Тичина, Франко (Каменяр).

For Melnychuk's antroponymicon, one of the central images of the theme group "national literature" is the figure of Hryhorii Savych Skovoroda, whose view system is based on the Christian teaching. Let us consider the lines: “ковилі вогненні / звідусюди / $i$ чадних квітів / трунна їдь / $і$ десь на дні геєнни/ люди / $і$ сам саваоф / на дні стоїть / $і$ розмовляє з сковородою / як світ иеей витягти / на світ" (Melnychuk, 2006: 293). The biblical anthroponym denoting Christ and the philosopher's surname are successfully blended into the mythological worldview of the poet's linguistic consciousness. The folk fairytale images with superpowerful negative meaning ковилі вогненні, чадних квітів трунна $\ddot{\partial}$ b are representatives 
of the evil in its eternal war with the good. In the poet's worldview, Ukraine as part of the totalitarian USSR appears as Gehenna - according to the New Testament, is it a place in the south of Jerusalem where children were burned as sacrifices to Moloch and Baal. The place got a reputation of a dump, site of conflagration, constant punishment (Rajken, 2005: 29). Among the linguistic markers of the author's passionarity is the idiom витягати на світ, which, used as part of the homonymous phrase, creates a new lexical meaning - to save. T. Melnuchuk is sure that in search of a way to get Ukraine out of the modern hell, it is worth referring to the wisdom of God's commandments, whose guide for Ukrainians was the enlightener Hryhorii Skovoroda. That is, in the author's linguistic mind, the image of the national philosopher grows into the image of the apostle of Christ in Ukraine.

The figure of the national prophet - Taras Shevchenko - is among the images with superpowerful energy in T. Melnychuk's poetic texts. It is proved by a number of anthroponymic formulas, in particular: Тарас, Тарас Шевченко, Шевченко, Шевченко Тарас, Кобзар. In the author's worldview, the founder of Ukrainian nationalism ranks with the Christian Saviour, for ехатрlе: "палає все людське / гніздов'я / а погасить / не стане свит / не стане ні води / ні крові / не стане нас / й по морю синьому / дніпрові / Христос іде / а з ним / Тарас”" (Melnychuk, 2006: 293). In this context, we can see an allusion to the evangelic event when Christ and his apostle Peter were walking on the waters of the Galilean Sea, where the God's son orders the boisterous chaos to calm down (Rajken, 2005: 164). As can be understood, the poet, who is a Christian, sees Christ and Taras Shevchenko - God's follower, an apostle - as the saviours and protectors of the nation. The biblical onym and the name denoting the person of supreme significance for the nation begin with the capital letter.

One of the features of Melnychuk's use of proper names is his naming the personalities of national value by a one-word construction - first name, for example: " $\mathrm{Hi}$, Вітчизна - $\epsilon$ ! Й вона - / Сдина! / С Вітчизна! В мене - не у вас! / Це вона упала на коліна / І иілує землю, u, сходив Tapac” (Melnychuk, 2003: 234). The climatic sense clot of the context, where "great energy seethes" (Dyvoovyd: Antolohiia ukrainskoi poezii KhKh stolittia, 2007: 11), is the underlined phrase, in which, due to sudden semantic change, the seemingly negative idiom is transformed into a manifestation of the spirit of rebellion - a deep gratitude to the national prophet. Such a technique fully reveals the mental essence of a Ukrainian patriot - despite tremendous obstacles, to hold with dignity before the enemy, inspired by the vital energy of spiritual wells. The representatives of the stoicism of the national character are rendered by the vitalistic foundations of the linguistic mind of the imprisoned poet, which are based on the indisputable faith in Ukraine's statehood.

\section{Conclusions}

Using the anthroponymicon of the historical and literary discourses, T. Melnychuk represents Ukrainian national linguistic worldview in full. Through the use of onyms as a national-cultural component, the author gets into historical-philosophical reflections, forming an associative field of Ukrainian identification.

In the author's linguistic world, we see a number of proper names the denote the poeticised by Ukrainians legendary personalities of different historic periods: the epoch of the Kyivan Rus and the time of the liberation struggle of the $17^{\text {th }}-19^{\text {th }}$ centuries, in particular, the representatives of the Cossack time and the images of vigilantes. These historic personalities, who are symbols of stoicism in fighting the aggressors, became a mental national-cultural code. Thus, ethnically marked anthroponyms give T. Melnychuk's works a distinctive national colouring. 
The anthroponymic material, which outlines the national literary circle, transforms in the author's linguistic mind and demonstrates the linguistic creativity of his personality, becomes an integral part of the source base of the corpus of national ethnolinguistics.

A skilful combination in the contexts with anthroponyms of the vocabulary of discourses of different historic epochs, folk-poetic and biblical images as well as occasional, idiomatic and colloquial linguistic units makes them a powerful expresser of comprehending Ukrainian culture through the semantic connotation of Melnychuk's linguistic space.

An expressive national-cultural component of the author's individual style is a wide use of the anthroponymic material in the poetic works written in the form of historical song, kolomyika, where the images traditionally "grow" from Ukrainian folk songs and mythology. Such a feature makes folklore one of the main guidelines of T. Melnuchuk's linguistic works, which determines the originality of his style manner. Further studies of the onym system of the sixtier poet's linguistic world, in particular the toponymical units, looks to us a topical issue.

\section{References}

Bondar O. I. Temporalni vidnoshennia v suchasnii ukrainskii literaturnii movi: Funktsionalno-onomasiolohichnyi aspekt [Temporal relations in modern Ukrainian standard language: the Functional-onomaseological aspect] : avtoref. dys ... dokt. filol. nauk: 10. 02. 01. K., 1998. 33 s. [in Ukrainian]

Dyvoovyd: Antolohiia ukrainskoi poezii KhKh stolittia [Dyvoovyd: Antology of the Ukrainian poetry of the $20^{\text {th }}$ sentury] / Uporiad., peredm., dovidky pro avt. I. Luchuka. Compilation, introduction, information about the authors by I. Luchuk Ternopil: Navchalna knyha - Bohdan, 2007. 11 s. [in Ukrainian]

Zhaivoronok N. V. Ukranska etnolinhvistyka: Narysy [Ukrainian ethnolinguistics: Sketches]: Navch. posib. dlia stud. vyshch. navch. zakl. K.: Dovira, 2007. 262 s. [in Ukrainian]

Zelenenka I. A. Obrazna systema liryky Tarasa Melnychuka [The image system of Taras Melnychuk's poems] : avtoref. dys... kand. filol. nauk: 10.01.01 / I. A. Zelenenka; Lvivskyi natsionalnyi un-t im. Ivana Franka. L., 2009. 15 s. [in Ukrainian]

Melnychuk T. Tvory : v 3 t. [Works: in 3 volumes] / T. Yu. Melnychuk. Kolomyia : Vik, 2003. T. 1. 254 s. [in Ukrainian]

Melnychuk T. Tvory : v 3 t. [Works: in 3 volumes] / T. Yu. Melnychuk. Kolomyia : Vik, 2003. T. 2. 256 s. [in Ukrainian]

Melnychuk T. Tvory : v 3 t. [Works: in 3 volumes] / T. Yu. Melnychuk. Kolomyia : Vik, 2006. T. 3. Kn. 1. 496 s. [in Ukrainian]

Melnychuk T. Tvory : v 3 t. [Works: in 3 volumes] / T. Yu. Melnychuk. Kolomyia : Vik, 2007. T. 3. Kn. 2. 343 s. [in Ukrainian]

Rylov Yu. A. Imena sobstvennye v indoevropejskih yazykah. Romanskaya i russkaya antroponimika : [monografiya] [Proper names in Indo-European languages. Roman and Russian anthroponymics] / Yurij Alekseevich Rylov. M. : Vostok-Zapad, 2006. 314 s. [in Russian]

Slovar biblejskih obrazov [Dictionary of biblical images] / pod obsh. Red. L. Rajkena, Dzh. Uilhojta, T. Longmana III. SPb., 2005. 1423 s. [in Russian]

Teliya V. N. Russkaya frazeologiya. Semanticheskij, pragmaticheskij i lingvokulturologicheskij aspekty [Russian phraseology. The semantic, pragmatic and linguocultural aspects] I V. N. Teliya. M. : Shkola «Yazyki russkoj kultury», 1996. 288 s. [in Russian]

Ukrainski narodni dumy ta istorychni pisni [Ukrainian folk dumas and historical songs], Kyiv: Veselka, 1990, s. 130-134. [in Ukrainian] 